\title{
Medical Geology - the European perspective
}

\author{
Olle Selinus \\ Geological Survey of Sweden, Uppsala
}

Jose A. Centeno

U. S. Armed Forces Institute of Pathology,

Washington
Robert B. Finkelman

Dept. of Geosciences, University of Texas at Dallas

\section{Mark Cave}

British Geological Survey, Keyworth, Nottingham

\section{Introduction}

Medical geology is the science dealing with the influence of geologic factors on the distribution of health problems in humans and animals. This is a complicated subject and interdisciplinary in nature, requiring the contribution from very different scientific fields to provide solutions to these problems. Accordingly, Medical Geology is a rapidly growing discipline that has the potential of helping medical and public health communities all over the world to pursue a wide range of environmental and naturally-induced health issues.

Practitioners of Medical Geology have five principal goals

1) To identify geochemical anomalies in soils, sediments, and water that may adversely impact human and animal health;

2) To identify the environmental causes of known health problems and, in collaboration with biomedical/public health researchers, seek solutions to prevent or minimize these problems;

3) To evaluate the beneficial health effects of geologic materials and process;

4) To reassure the public when there are unwarranted environmental health concerns associated with geologic materials or processes; and

Addresses: O. Selinus: Uppsala SE-751 28, Sweden, e-mail: olle.selinus@sgu.se R. B. Finkelman: FO 21800 West Campbell Road Richardson, TX 750833, USA

J. A. Centeno: 6825 16th Street NW Washington, DC 20306-6000, USA M. Cave: Kingsley Dunham Centre Nottingham, NG12 5GG, UK

Received: October 6, 2008; accepted: October 14, 2008 
5) To forge links between developed and developing countries to find solutions for environmental health problems.

\section{$A$ wide range of issues}

Among medical geology issues are examples of both deficiency and toxicity of trace elements. Goiter is a widespread and potentially serious health problem caused by iodine deficiency. In many locations the deficiency is attributable to low concentrations of iodine in the bedrock. Similarly, deficiency of selenium in the soil is sometimes suggested as the principal cause of juvenile cardiomyopathy and muscular abnormalities. Overexposure to arsenic is one of the most widespread medical geology problems, affecting more than one hundred million people in Bangladesh, India, China, Europe, Africa and North and South America. Arsenic exposure is primarily due to naturally high levels in groundwater but combustion of mineralized coal has also caused arsenic poisoning. Dental and skeletal fluorosis impacts the health of millions of people around the world and, like arsenic, is due to naturally high concentrations in drinking water and, to a lesser extent, coal combustion. Other medical geology issues include geophagia, the deliberate ingestion of soil, exposure to radon, and ingestion of high concentrations of organic compounds in drinking water. Geoscience and biomedical/public health researchers are teaming up to help mitigate these health problems as well as collaborate on various non-traditional issues for geoscientists, such as vector-borne diseases.

\section{Development in Europe}

Ancient philosophers and physicians in countries such as Greece realized the importance of how geology influences health, although it was not until the advent of modern medicine in the 19th century that elements essential to health were finally recognized.

The Greek philosopher Hippocrates (400 B.C.) is considered by most scientists to be the founder of medical geology. He recognized that environmental factors affected the distribution of disease. Hippocrates noted in his treatise, On Airs, Waters, and Places, that under certain circumstances, water "comes from soil which produces thermal waters, such as those having iron, copper, silver, gold, sulfur, alum, bitumen, or nitre", and such water is "bad for every purpose". Another example is that of Vitruvius, a Roman architect in the last century B.C., who recognized potential health hazards related to mining, noting that the water and pollution near mines posed negative health threats. Later, in the first century A.D., the Greek physician Galen reaffirmed the potential danger of mining activities when he noted that acid mists are often associated with the extraction of $\mathrm{Cu}$ from the ground (Bowman et al. 2003). 
Contemporary archaeologists, osteologists and historians provide us with evidence that poor health reflected in the tissues of prehistoric cadavers and mummies can be often be linked to past detrimental environmental conditions. Goiter for instance, the result of severe iodine deficiency, was widely prevalent in ancient China, Greece, Egypt as well as in the Inca state of Peru. This condition was often treated with seaweed, a high source of iodine, which indicates some degree of knowledge that these ancient civilizations had concerning the treatment of dietary deficiencies through the use of natural supplements.

Besides element deficiencies the use of heavy metals in everyday ancient society introduced the negative effects of toxicity-related problems. Lead has been exploited for over six millennia, with significant production beginning about 5000 years ago and increasing steadily until finally peaking about 2000 years ago. During the Roman Empire it has been estimated that the annual production of $\mathrm{Pb}$ approached 80,000 tons. During the Roman Empire $\mathrm{Pb}$ usage exceeded 550 grams per person per year. The main uses were for plumbing, architecture and shipbuilding. Lead salts were used to preserve fruits and vegetables and $\mathrm{Pb}$ was also added to wine to stop further fermentation and to add color or bouquet. Large amounts of $\mathrm{Pb}$ usage in the daily life of Roman aristocracy had a number of negative health implications, including: epidemics of plumbism and saturnine gout, high incidence of sterility and stillbirths as well as mental incompetence. Physiological profiles of Roman Emperors dating between 50 B.C. and 250 A.D. suggest that the majority of individuals suffered from lead poisoning. In turn, it is generally believed that a contributing factor to the fall of the Roman Empire, in 476 A.D., may have been the result of the excessive use of lead.

Formal recognition of the medical geology sub-discipline appears to reside with Ziess who first introduced the term 'geomedicine' in 1931, and at the time considered it synonymous with 'geographic medicine' which was defined as "a branch of medicine where geographical and cartographical methods are used to present medical research results". In the 1970s Låg in Norway redefined the term geomedicine as "the science dealing with the influence of ordinary environmental factors on the geographic distribution of health problems in man and animals". In the 1990s Låg was very productive in organizing annual conferences and producing several books under the aegis of the Norwegian Academy of Sciences (Låg 1990).

In 1997 an International Union of Geological Societies working group on medical geology was established. Since then there has been a rapid development of this field. Discussions focused on the organization and the feasibility of preparing a new textbook on medical geology. In September 2000 about 50 people participated in a meeting and workshop in Uppsala, Sweden. A two-day seminar was held on medical geology, under the title of "The Geochemical Environment and Human Health", resulting in a proceedings volume (Skinner and Berger 2000). The workshop participants discussed the future work of the group, 
newsletters, an internet home page, generating other informational material, and publishing an interdisciplinary book on medical geology for a broad multidisciplinary audience.

In 2000 the International Geologic Correlations Programme (IGCP) established a new project "IGCP 454: Medical Geology". This initiative provided, for the first time, the opportunity for scientists (geoscientists, physicians, geographers, veterinarians, etc.) from developed and developing countries to come together in a truly international and inter-disciplinary forum and to identify and tackle significant environmental health problems. At the same time the International Council of Science in Paris (ICSU) provided a significant grant for developing medical geology all over the world. This eventually developed into the International Medical Geology Association, IMGA (Selinus et al. 2008).

\section{Medical geology issues in Europe}

Balkan endemic nephropathy (BEN) is a serious kidney disease that occurs in clusters of rural villages located in tributary valleys of the Danube River in the Balkan Peninsula (the former Yugoslavia, Romania, and Bulgaria). It is believed that at least 25,000 persons are suffering from BEN or are suspected of having the disease, and that the total number of people at risk may exceed 100,000. BEN was first described as a distinct medical entity in 1956, but it may have existed undescribed for many centuries. Work by the U.S. Geological Survey (USGS) and others in the early 1990s noted the close correlation between the location of the affected villages and the occurrence of coal deposits, specifically lignite deposited in the Pliocene Epoch 5.3 million to 1.6 million years ago. Further research showed that the well water in affected villages has measurable amounts of organic compounds such as polycyclic aromatic hydrocarbons (PAH's) and aromatic amines that may be toxic. The nearby Pliocene lignite deposits are unusual in that these coals release large amounts of organic substances when leached with water or other polar solvents. These coal deposits, therefore, could be a source of toxic organic compounds such as those found in the well water from the affected villages. Consumption of well water contaminated with toxic organic compounds derived from the coal may be implicated in the onset of BEN. The study of BEN demonstrates the value of a close working relationship between the geoscience and medical communities. Medical geology research is needed to determine whether these cancers are caused by toxic organic compounds leached from coal. Coal deposits are present worldwide, and several direct links between coal combustion and disease in humans have been documented. Studies of BEN indicate that contamination resulting directly from coal deposits could affect human health in susceptible population groups. In Europe it has been found that this is also the case in Greece, Turkey and Portugal (Feder et al. 1991; Tatu et al. 1998; Orem et al. 1999). 


\begin{abstract}
Arsenic
Arsenic and arsenic-containing compounds are human carcinogens. Exposure to arsenic may occur through several anthropogenic processes, including mining residues, pesticides, pharmaceuticals, glass and microelectronics, but the most prevalent sources of exposure today are natural ones. Exposure to arsenic occurs via the oral route (ingestion), inhalation and dermal contact. Drinking water contaminated by naturally-occurring arsenic remains a major public health problem (Centeno et al. 2002). The source of arsenic is geologic, the element being present in many rock-forming minerals. There is growing concern about the toxicity of arsenic and the health effects caused by exposure to low levels in the geochemical environment (Centeno et al. 2008). The danger to human health due to arsenic poisoning has been recognized by the WHO; the provisional guideline value for arsenic in drinking water has been lowered from $50 \mu \mathrm{g} / 1$ to $10 \mu \mathrm{g} / \mathrm{l}$. Acute and chronic arsenic exposure via drinking water has been reported in many countries (Centeno et al. 2007). Among the countries that have welldocumented case studies of arsenic poisoning are Bangladesh, India (West Bengal), Taiwan, China, Mexico, Chile and Argentina, but also several countries in Europe, for example the UK, Hungary, Sweden, Slovakia, etc. A recent report has also linked arsenic in drinking water to an elevated incidence of bladder cancer in the northeastern United States. The common symptoms of chronic arsenic poisoning are depigmentation, keratosis and hyperkeratosis (Centeno et al. 2002; Smedley and Kinniburgh 2005).
\end{abstract}

\title{
Asbestos
}

Asbestos and natural asbestiform compounds are among the most significant fibrous minerals with health implications. The major forms of asbestos extracted commercially were chrysotile (white asbestos) and the asbestiform amphiboles crocidolite (blue asbestos), amosite (brown or gray asbestos), anthophyllite asbestos, and tremolite. Elevated exposures are known to be associated with asbestosis. It is generally thought that the asbestiform amphiboles are more carcinogenic than chrysotile asbestos, with lower level exposures of the former associated with increased risk of mesothelioma and lung cancer.

Asbestiform compounds may be present in soils or rocks from which they can be dispersed to adjacent human populations. In general, the risks posed by exposure to dust containing naturally-occurring asbestos have not been as thoroughly investigated or described as those arising in occupational contexts. The relationship is best established in certain regions in Turkey, where inhabitants are exposed to erionite, a form of fibrous zeolite, present in the volcanic tuffs used as building stone. Exposure to erionite fibers, which circulate through the houses and streets of affected villages, has been linked to markedly elevated rates of mesothelioma. In one village, the incidence rates are many times higher than expected compared with the general population. In some zeolite-rich 
villages, malignant mesotheliomas are responsible for more than $50 \%$ of the total deaths (Dogan et al. 2008).

A number of fibrous minerals, including anthophyllite and tremolite, have also been identified in the soils of Mediterranean and Central Europe and Turkey. Inhaled materials from these sources have been linked to pleural plaques in neighboring agricultural communities. A common exposure pathway is through the domestic production and use of products made from local soils. One such product is the whitewash made from "luto soil" in the Metsovo region of Greece. Analysis of samples of the whitewash material revealed high levels of asbestiform minerals, particularly tremolite. Radiographic screening has detected pleural calcifications in almost half of inhabitants in some northwestern Greece villages with no known occupational exposure to asbestos fibers. In the early 1980s the incidence of mesothelioma deaths in the Metsovo region was about 300 times greater than expected in a non-exposed population. High prevalence of pleural calcification has also been reported for inhabitants of several rural regions of northeastern Corsica, Turkey and Cyprus where whitewash containing tremolite asbestos has been used. Another fibrous mineral from the soil, sepiolite, has also been linked to pleural calcification in Bulgarian populations. An association has also been reported between mesothelioma and volcanic dust containing fluoroedenite, a fibrous amphibole chemically similar to tremolite, in a region of Sicily (Dogan et al. 2008).

\section{Slovakia}

In Slovakia, as well as in many other countries, Medical Geology issues are being addressed by geologic projects financed from the state budget. One such project being conducted by the Geological Survey of the Slovak Republic is the evaluation of the potential influence of the geochemical environment on the health state of the population in the region of the Spišsko-Gemerské Rudohorie Mts. (Rapant and Krcmova 2008).

The aim of this project is to verify methodical principles of evaluation of the influence of either excess or deficiency of chemical elements within the geologic environment on the health of the population in one of the most contaminated regions of the Slovak Republic. Methodological interconnections of geochemical and medical data and their further mutual assessment have been developed, aiming at the final analysis of environmental and medical risks. A methodology has also been developed for evaluating and systematically mapping environmental health risks caused by harmful elements in Slovak groundwater. Applying national geochemical databases, Rapant and Krcmova (2008) have dealt with the feasibility of calculating and visualizing health risk from arsenic groundwater contamination. Potential health risks have been assessed based on existing geochemical data in accordance with present methodological procedures established for human health risk assessment (US EPA, 1999). Screening analysis 
has been used to estimate the contribution to total chronic risk from groundwater contamination by potentially toxic elements including $\mathrm{As}, \mathrm{Ba}, \mathrm{Cd}, \mathrm{Cu}, \mathrm{Hg}, \mathrm{Pb}, \mathrm{Sb}$, $\mathrm{Se}$ and $\mathrm{Zn}$. These results point out a significant contribution by arsenic to total risk in about $10 \%$ of the Slovak territory. The areas characterized with high health-risk levels are mainly geogenically contaminated. High carcinogenic risk was determined in 34 of 79 districts and in 528 of 2924 municipalities.

The environmental risk, defined as the possibility of impairment of biotic or abiotic components of the environment, derived from geologic sources, has also been estimated for the whole of Europe. The assessment was based on data obtained from the Geochemical Atlas of Europe. The assessment method was based on the calculation of two-step environmental risk index values for individually analyzed water, soil and sediment samples. Environmental risk quotients are first calculated for each analyzed chemical element or compound that exceeds the limit for risk values, and their sum is then calculated. The risk at each site was defined and classified as negligible, low, medium, high, very high or extremely high. The results are presented as risk maps covering the 26 countries of Europe. The calculated maps delineate regions where highly elevated concentrations pose a risk to the environment, or where the action triggers for soil, sediment or water contamination should be revised, using the high local baseline (Rapant et al. 2008).

\section{Scandinavia}

In Sweden, research on coronary heart disease and hard water began in the 1960s. Later, a large study was carried out on Type 1 diabetes in children, which provided evidence for a correlation between high contents of $\mathrm{Zn}$ in drinking water and this type of diabetes (Haglund et al. 1996). In the 1980s, when thousands of moose died in Sweden, close collaboration between veterinarians and geochemists showed that this disease was the result of liming of acidified areas (Selinus and Frank 1999; Selinus et al. 1996). The liming mobilizes molybdenum in bedrock and soils, causing a disturbed $\mathrm{Cu} / \mathrm{Mo}$ ratio which is critical for the health of ruminants. Much attention has also been focused on the health effects of radon and, in recent years, on the effects of natural arsenic in drinking water (Selinus et al. 2005). These are just a few examples of research activities in medical geology in Sweden undertaken as a close collaboration between geochemists and medical scientists, epidemiologists, toxicologists, veterinarians, etc. Activities have also been carried out with the Royal Swedish Academy of Sciences, which resulted in a special publication of their journal AMBIO (AMBIO, 2007).

In Norway, problems have been known for a long time in human as well as veterinary health. As an example, the connection between iodine deficiency and goiter, most prevalent in areas situated far from the ocean, was already known in the 1920s (Låg 1990). A number of investigations have been performed over the 


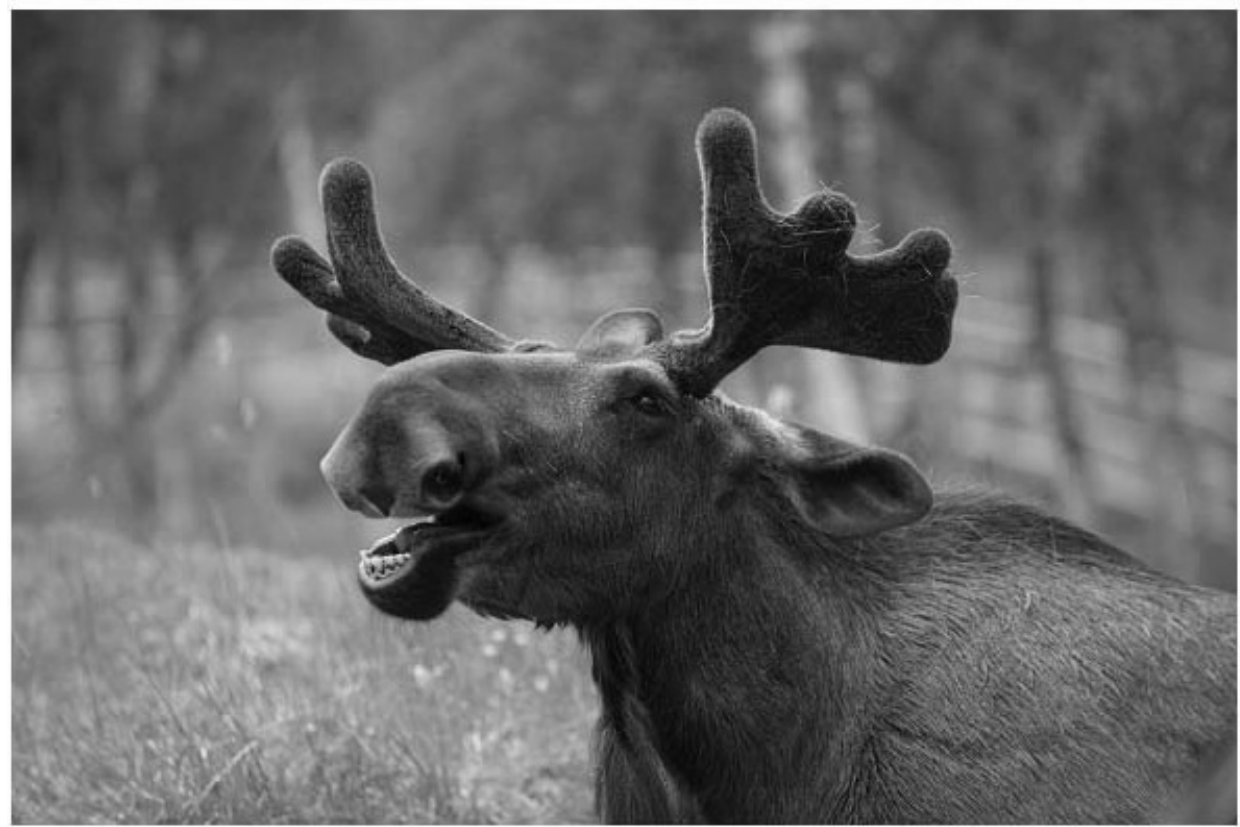

Fig. 1

Moose

years on deficiency problems in animal husbandry related to low abundance of essential trace elements in pasture soils. Currently a large-scale geographical study is being carried out on the status of essential trace elements in grazing domestic ruminants in Norway, and the factors that determine this status. The Geological Survey of Norway has carried out such research since 1971.

In Finland, during the past few decades, studies of the effect of selenium, arsenic, radon and certain other substances such as asbestos, on human health have been carried out (Koljonen 1975; Szalay et al. 1981; Lahermo et al. 1998; Kokki et al. 2001; Kurttio et al. 2006). There were also recent studies of environmental risk assessment and the spatial variation of certain chronic diseases in relation to the geologic or geochemical environment. GIS and geo-referenced data allow studies that benefit from a flexible geographical scale, for example grid cells instead of administrative boundaries. During the last ten years the Geological Survey of Finland (GTK) and the National Public Health Institute (KTL) have carried out studies of the spatial variation of acute myocardial infarction (AMI) (Kousa et al. 2004) and the incidence of childhood Type 1 diabetes (T1DM) in relation to the geochemistry of local groundwater (Moltchanova et al. 2004). Environmental risk assessment methods are increasingly applied to investigate small and large-scale environmental problems and their impact on human health. The GTK, the KTL and the University of Kuopio have recently founded the Environmental Risk Assessment Centre (ERAC) to conduct scientific research and to develop new projects. 


\section{Health issues at BGS in UK}

The geology of Great Britain is varied and complex and gives rise to the wide variety of landscapes found across the island. For its size, the geology of the UK is probably one of the most complex in the world. In the 21st century the interaction of humans with geology in the UK is perhaps lower than in the past. Drinking water comes from treated public supplies, not from local boreholes, and much of the food eaten is supplied by large retail outlets and is not grown locally. With concerns about genetic modification of foodstuffs, chemical pollution and contamination of food and the desire for the ultimate in freshness there is, however, a small but significant segment of the population that grows its own fruit and vegetables in back gardens and allotments. In the UK, allotments are small parcels of land rented to individuals, usually for the purpose of growing food crops. There is no set standard size but the most common plot is ca. 250 square meters; there are probably of the order of 300,000 plots in cultivation in the UK. For this section of the population the geology underlying their soils may well have a significant effect on their health and well being. The other large segment of the population which comes into contact with the soil environment, and is perhaps more vulnerable to health problems, are children. Play activities in gardens and parks can bring children in contact with soil and its subsequent oral ingestion due to hand-to-mouth activity.

Interestingly, it is the concern of government with the contamination of land from anthropogenic activity such as industrial, mining and waste disposal activities that has brought the natural geochemistry to the fore. In 1987 the Interdepartmental Committee on the Redevelopment of Contaminated Land (ICRCL Guidance Note 59/83) set out Trigger Values for a number of contaminants in soils including potentially toxic metals. These indicated concentrations of acceptable and unacceptable risk. More recently (Department for the Environment Food and Rural Affairs and the Environment Agency, 2002) new guidelines known as CLEA (Contaminated Land Exposure Assessment) superseded the ICRCL values by more comprehensive soil guideline values (SGV) based on toxicology and human exposure to soil contamination under different land use scenarios. The SGV are indicators for "intervention" either in the form of further detailed risk assessment and/or remediation. Legislation relating to the identification of contaminated land and the suitability of land for redevelopment has led local authorities to apply the principles specified in CLEA and in certain areas of the UK where the concentration of some potentially toxic metals in soils, of which arsenic was most common, were causing some concerns. Over a similar time scale there was increasing interest in the natural geochemistry of the UK, driven in the first instance by the need to identify mineral resources. Stream sediment geochemical surveys of the UK (Johnson et al. 2005) were showing clear patterns of Potentially Harmful Elements (PHE) at elevated concentrations. Subsequent soil mapping (Johnson et al. 2005) aimed more at environment and health investigations showed that the patterns for 
arsenic could be linked to the geology of the underlying parent material and were geogenic rather than man-made phenomena. A recent publication (Appleton et al. 2008) has combined the stream sediment and soil data to produce a national-scale UK estimate of soil arsenic concentrations. This study showed that the largest areas with the highest concentrations $\left(>30 \mathrm{mg} \mathrm{kg}^{-1}\right)$ occur in the English Lake District, western Wales, the northeast Midlands going into the north Midlands and southwest England.

The British Geological Survey has carried out a number of studies (Cave et al. 2003; Palumbo-Roe et al. 2005; Wragg 2005; Cave et al. 2007; Wragg et al. 2007) investigating the human bioaccessibility of arsenic in soils with elevated arsenic from the NE Midlands and in SW England. The investigations were based on an in vitro physiologically based extraction test (PBET) which mimics the physical and chemical environment of the human stomach and the upper intestine. The test measures the bioaccessibility of the arsenic in the soil (the amount of arsenic liberated into solution from the soil during the PBET test). The NW Midland soils developed over ironstone parent materials were found to have $<10 \%$ of their total arsenic content in bioaccessible form. In SW England, where the arsenic was associated with natural mineralization, total concentrations generally higher than in the NW Midlands, especially where mining activities were carried out, had higher levels of bioaccessible arsenic (c. 10-20\%). Geochemical testing including sequential extractions shows that the bioaccessible arsenic is associated with carbonates and fine-grained $\mathrm{Fe} / \mathrm{Mn}$ oxy-hydroxides, whereas the unavailable fraction is often bound to highly crystalline Fe oxides (goethite, hematite). The studies of the ironstone soils has shown that the bioaccessible fraction of arsenic in these soils is unlikely to be a health risk and that in the mineralized areas in the southwest, especially where the highest total arsenic concentrations occur, that there could be potential health risks. It has been shown that humans living in a high arsenic area in SW England do have elevated As in urine (Kavanagh et al. 1997).

To illustrate the potential problems with arsenic in the UK, the BGS recently completed a geochemical soil survey of the river Tamar catchment in the southwest of the UK (Rawlins et al. 2003). Figure 2 shows the location and the geology of the catchment along with the areas where mining activity has taken place. Figure 3 shows the concentration of arsenic in soil interpolated from chemical analysis of 450 samples taken over the catchment. Clearly a large proportion has soil concentrations exceeding the current UK soil SGV of $20 \mathrm{mg}$ $\mathrm{kg}^{-1}$. The very high concentrations of arsenic found in the south of the area coincide with the location of the Devon Great Consols arsenic mine which terminated operations in 1930. Work is currently under way, using the archive of soils collected from this area, to measure and map the bioacessibility of the arsenic in the soil. 

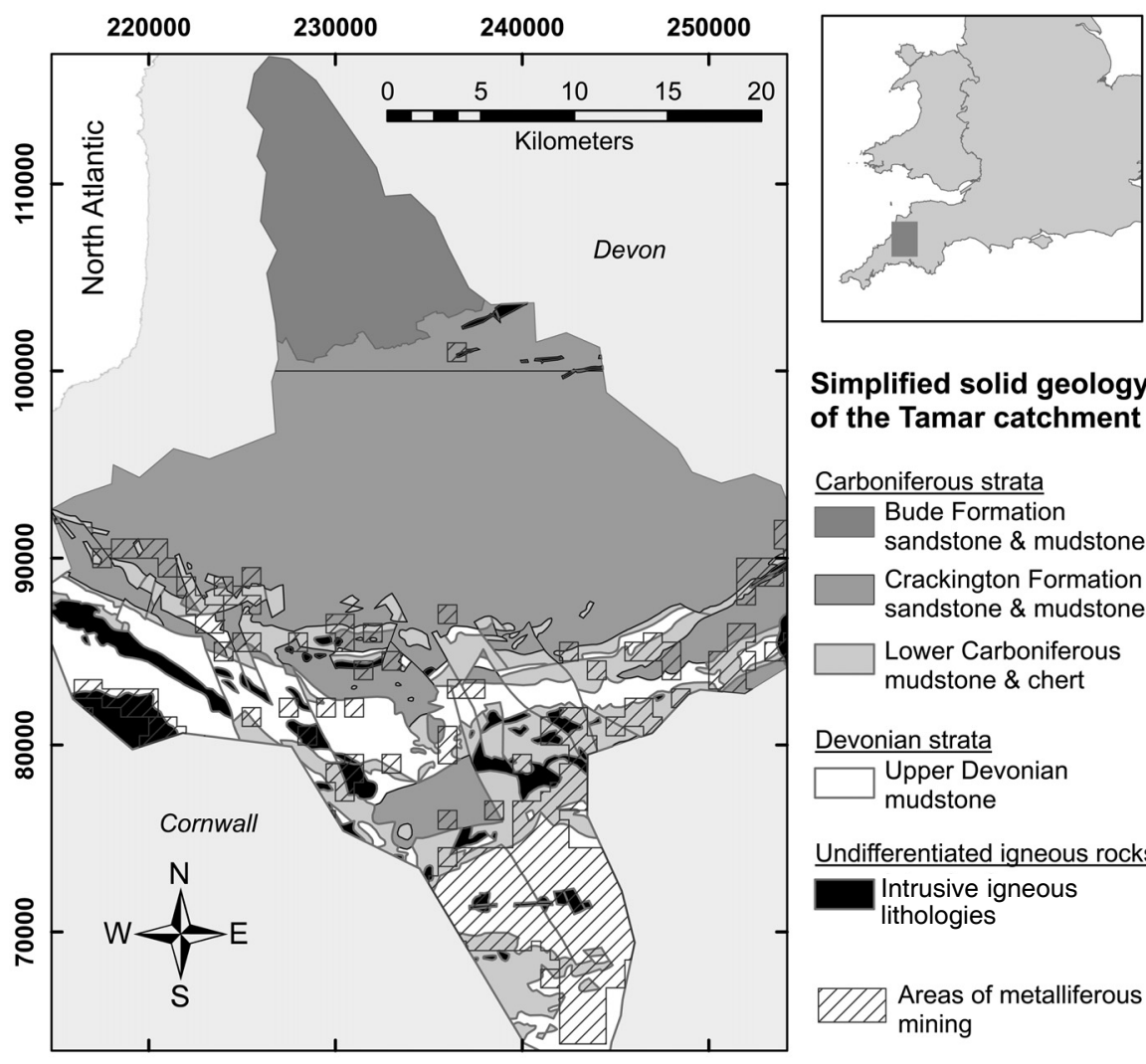

Simplified solid geology of the Tamar catchment

Carboniferous strata

Bude Formation

sandstone \& mudstone

Crackington Formation sandstone \& mudstone

Lower Carboniferous mudstone \& chert

\section{Devonian strata}

Upper Devonian mudstone

$\underline{\text { Undifferentiated igneous rocks }}$

Intrusive igneous lithologies

Fig. 2

Location and geology of the Tamar catchment in the UK

\section{Dust particles of geologic origin}

Dust particles of geologic origin are a widely dispersed component of the Earth's atmosphere, often forming extensive plumes that derive from volcanoes, dust storms, long-range transport episodes of desert dust, and displacement through natural processes such as landslides and earthquakes. These phenomena occur on all the major continents, including mobilization of Saharan dust to Europe and the Americas and regular blanketing of Chinese cities and the Korean peninsula by Asian dust storms. The elements and compounds which are transported by dust phenomena and which may potentially have an impact on human health are diverse, and include trace metals and metalloids, radioactive elements, fluoride, silicates, natural asbestiform compounds and alkali salts. Natural dust events may act to disperse pathogens and bioallergens, and the health implications of such phenomena - often occurring over considerable distances - have only recently been acknowledged. Geogenic dusts also have 


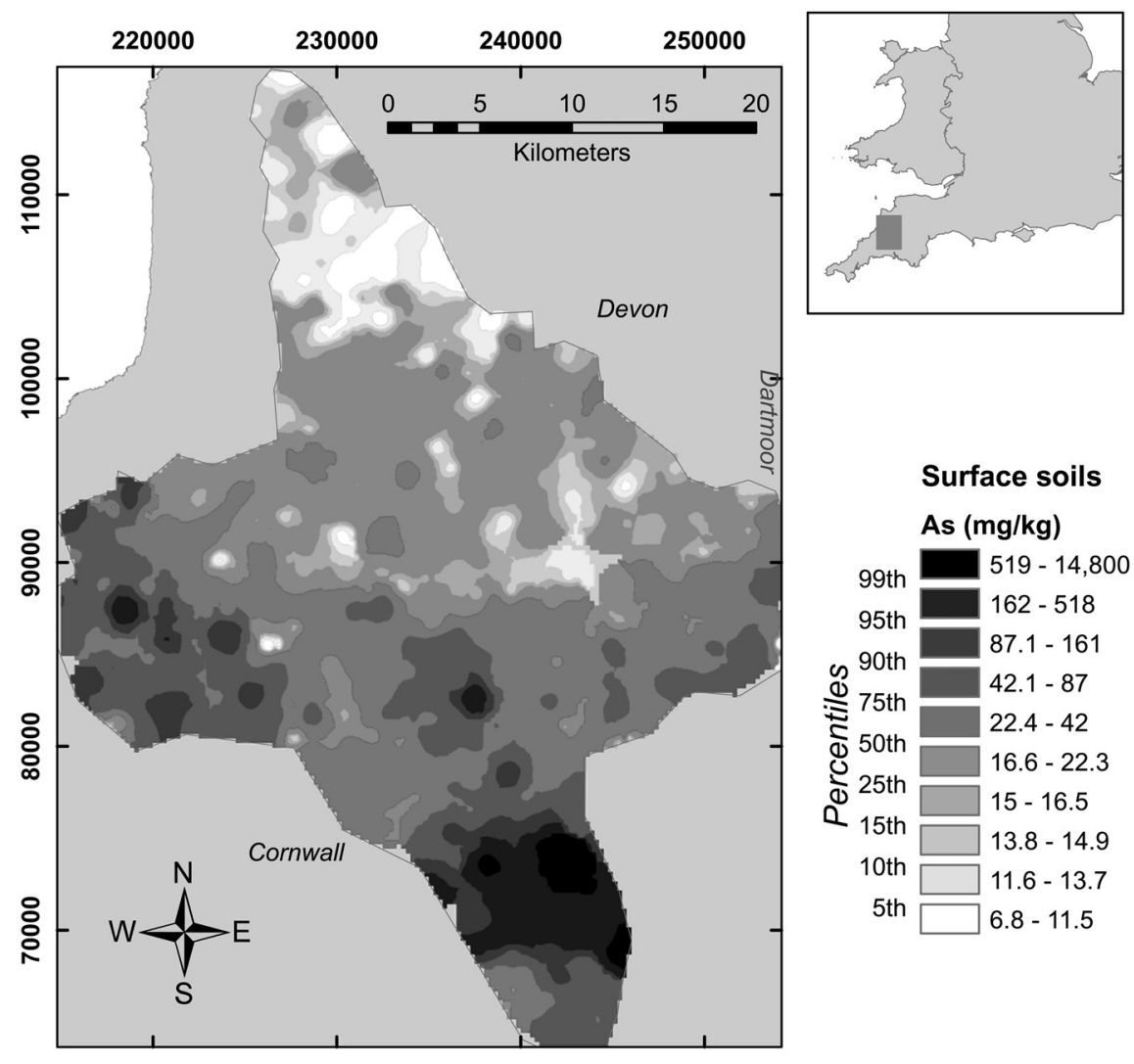

Fig. 3

Soil arsenic geochemical map of the Tamar catchment

indirect socio-economic impacts on health, with ongoing effects on water quality, food production and infrastructure, such as transport networks (Derbyshire 2005).

Dominant sources of natural dusts around the world are largely in or adjacent to the major drylands of the northern hemisphere. World dust emissions from dryland terrains may reach as much as 5 billion tons/year. The greatest of these includes a broad swathe of land across North Africa, the Middle East, northwest India, and central and eastern Asia - from the Western Sahara to the Yellow Sea. Africa is regarded as the greatest single source of minerogenic dust on Earth. This affects Europe significantly, especially Southern Europe but also most other parts of the continent. 


\section{Publications}

Information and news on medical geology has been published in many journals and books.

Some few selected examples from Europe can be mentioned. "Environmental Medicine," a book published in 2000 at the Karolinska Institute, Sweden, includes a chapter on medical geology. This book is used for courses for medical students at the Karolinska Institute and elsewhere. The BGS magazine, Earthwise, has published a thematic issue on Geology and Health (Earthwise 2001). A book, Geology and Health, edited by A.R. Berger and C. Skinner and published by Oxford University Press, covered all the presentations given at the meeting in Uppsala (Sweden) in 2000 (Skinner and Berger 2000). A special volume of the Journal of the BRGM (Geological Survey of France) on Medical Geology was published in 2007 (Geosciences et Santé 2007).

Two special issues on medical geology in developing countries have been published (Medical Geology in Developing Countries 2007, 2008). These include several European authors.

A book on Medical Geology has been published by Elsevier (Academic Press) in 2005. O. Selinus is chief editor and there are 6 associate editors (four from Europe): Brian Alloway, Jose Centeno and Bob Finkelman, Ron Fuge, Ulf Lindh, and Pauline Smedley (Selinus et al. 2005). Almost 60 distinguished authors from all around the world are represented. About $50 \%$ are geoscientists and about $50 \%$ are doctors, veterinarians and other public health scientists. In November 2005 Essentials of Medical Geology was recognized as a "Highly Commended" title in the Public Health category by the British Medical Association, a very prestigious acknowledgment. The book was also cited as one of the best published books in Public Health in 2005. They bestow awards upon publications "which are deemed to best fulfill the criteria of clinical accuracy and currency and which maintain a high standard of design and production".Essentials of Medical Geology also won a second prestigious reward in January 2006. It was one of two winners in the "Geology/Geography" category of the 2005 Awards for Excellence in Professional and Scholarly Publishing. The book has now thus been recognized in both communities for which it was intended. A third award was from Choice which publishes a list of Outstanding Academic Titles that are reviewed during the previous calendar year. This prestigious list reflects the best in scholarly titles reviewed by Choice and brings with it the extraordinary recognition of the academic library community

\section{Short courses and education}

Courses led by Jose Centeno, Bob Finkelman and Olle Selinus have been presented on 40 occasions all over the world, including ten European countries, and have been attended by several thousand students and professionals with backgrounds in geoscience, biomedical/public health science, environmental 
science, geography, engineering, chemistry, etc. The scientific topics of the course include environmental toxicology, environmental pathology, geochemistry, geoenvironmental epidemiology, extent, patterns and consequences of exposures to toxic metal ions, and analysis of geologic and biologic materials. The courses, generally 2 to 3 days in length, are intended for anyone interested in the effects of natural materials and natural geologic events on animal and human health. An

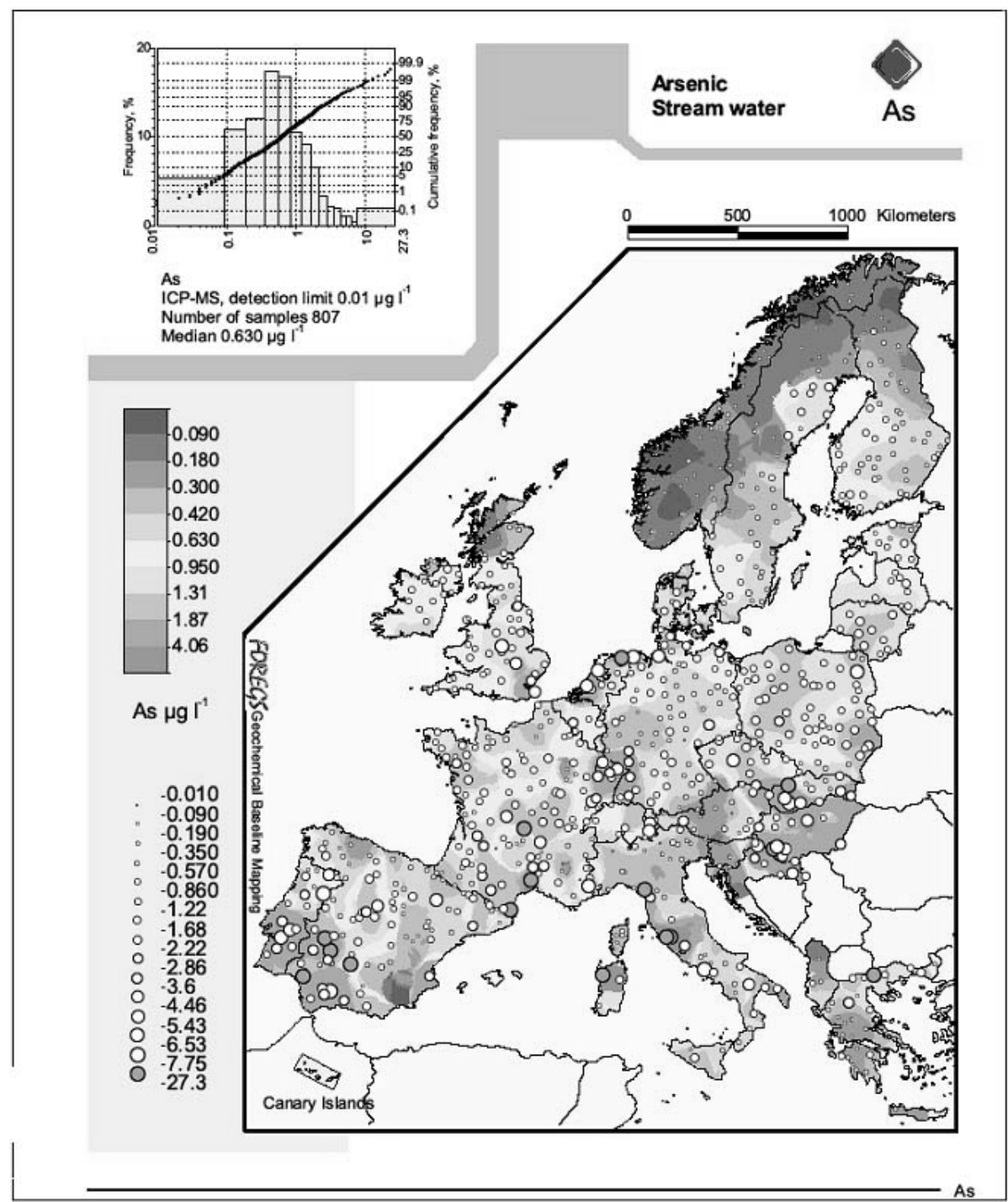

Fig. 4

Arsenic in stream water in Europe. From the FOREGS atlas. The original map is in colour. Therefore the correct colours can be seen in following (where all other European Foregs maps also can be seen): http://www.gtk.fi/publ/foregsatlas/index.php 
important objective of the courses is to provide an opportunity for forming contacts and networks between professionals working in different countries and on different aspects of environmental health issues.

The venues of courses held in Europe since 2001 include Russia (St. Petersburg) 2002, Lithuania 2003, Scotland 2003, Hungary 2004, Romania 2005, Turkey 2005, Ireland 2005, Sweden 2005, Portugal 2006 and Norway 2008.

Since the publication of Essentials of Medical Geology education in medical geology has also started all over the world, including universities in Europe. The first two students in Europe have also defended their PhDs in medical geology and one has started a career in medical geology in Australia. Two postdoctoral students (one epidemiologist and one geoscientist) have received training in medical geology research at the U.S. Armed Forces Institute of Pathology through the Registry on Medical Geology.

\section{European databases}

Geoscientists can take pride in their expertise in medical geology with the extensive geoscience databases and knowledge in GIS. In the 1970s and 1980s regional or national geochemical mapping projects were carried out in many countries. However, due to lack of standards the results were not satisfactory; thus standardization for geochemical mapping was particularly needed. The International Geochemical Mapping Project, the main aim of which was to establish standards, was accepted as part of the International Geological Correlation Program (IGCP 259) in 1988. Plans for a Global Geochemical Mapping Project using wide-spaced sampling were then accepted as the IGCP 360 project entitled "Global Geochemical Baselines" in 1995. The three major resulting aspects of the project were to determine the natural global distribution of various chemical elements and compounds and the present state of pollution in the surface environment, to delineate areas and geochemical provinces especially enriched in elements of economic importance, and to provide data on the regional distribution of compounds that are linked to human and animal health. As one further step the compilation of the "Geochemical Atlas of Europe" was carried out by the Geological Surveys of the European Union (EuroGeoSurveys).

The European survey covered 26 countries and provided information in different sample media of the near-surface environment (topsoil, subsoil, humus, stream sediment, stream water and floodplain sediment). This was the first multinational project, performed with harmonized sampling, sample preparation, and analytical methodology, producing high-quality compatible data sets across national borders. Over 60 determinands were established, 400 maps plotted and interpreted, most for total and aqua regia-extractable concentrations. The first phase of the project has been completed and the results published in a twovolume set, which is also freely available for viewing and downloading. Also the entire database can be downloaded free of charge (Salminen et al. 2005). 
148 O. Selinus et al.

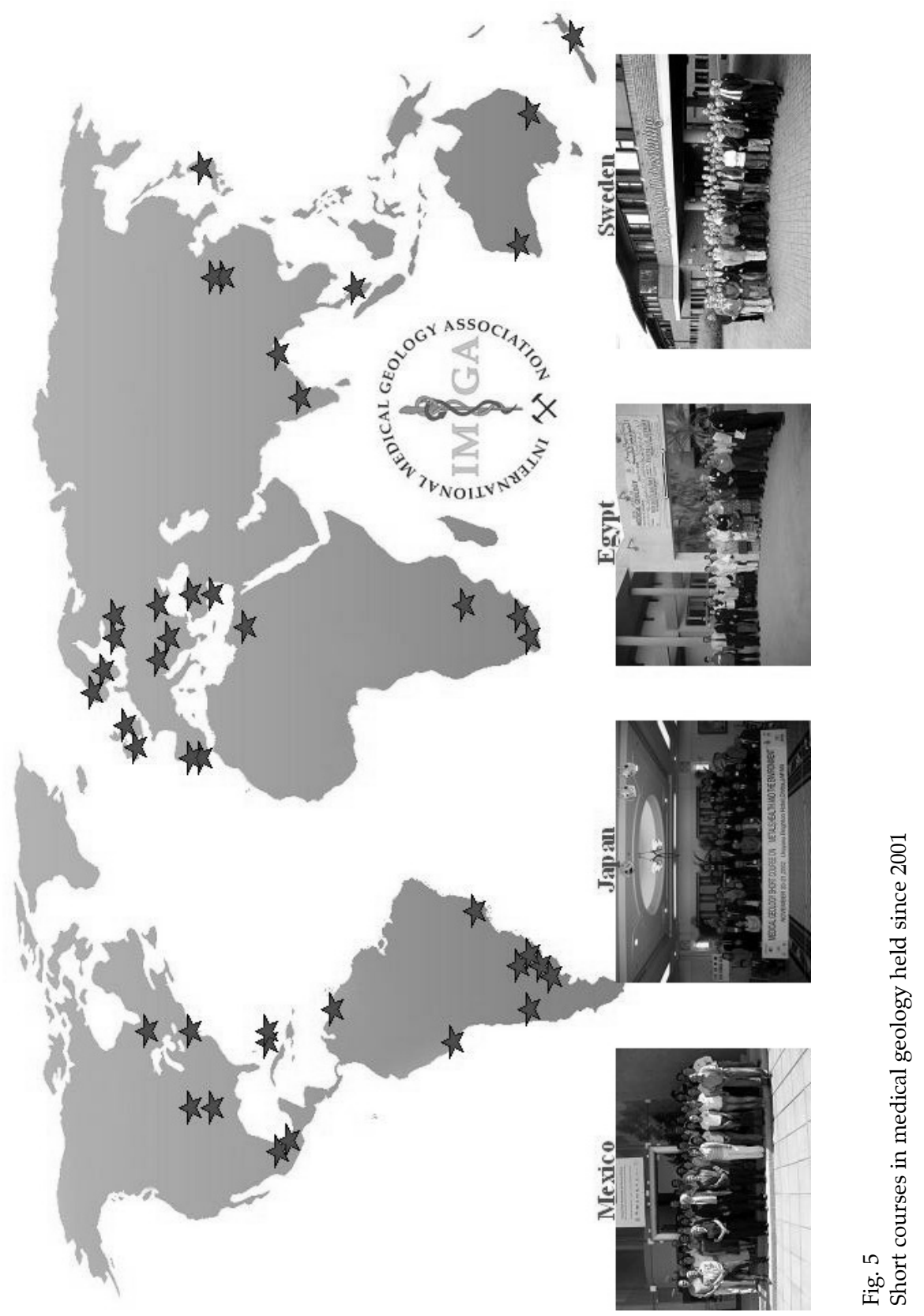

Central European Geology 51, 2008 
Another example of a database is the Baltic soil survey covering total concentrations of major and selected trace elements in arable soils from 10 countries around the Baltic Sea. Agricultural soils were collected from 10 European countries over a 1,800,000 $\mathrm{km}^{2}$ area surrounding the Baltic Sea. Large differences between element concentrations and variations can be observed for most elements when the different countries are compared. The database can be downloaded for free (Reimann et al. 2003)

In addition, the big Kola Ecogeochemistry Project should be mentioned. This is an Environmental Investigation in Arctic Europe. The Kola Ecogeochemistry Project is concerned with regional mapping of heavy metals and radioactivity pollution of terrestrial and aquatic ecosystems over an area of $188,000 \mathrm{~km}^{2}$ in the Barents Region, sulfur and trace element deposition, the impact of major industrial activity in the western Kola Peninsula, and the degradation of a particularly vulnerable arctic environment (Reimann et al. 1998).

\section{The future of medical geology including Europe}

The International Medical Geology Association (IMGA) was launched in January 2006 with one European president and two European councilors (UK and Romania). The association is the umbrella for regional divisions around the world. Among the Divisions are those for Europe, Russia and NIS and Southern Mediterranean

It is always risky to anticipate what the future holds. Nevertheless, we are confident that the future for medical geology still looks promising, notwithstanding the already rapid growth of the sub-discipline. The book Essentials of Medical Geology has received an overwhelmingly positive response. The reviews have been uniformly positive and the first printing has nearly sold out in less than a year. We anticipate that the book will stimulate the teaching of medical geology in collages and universities. The medical geology short course will continue to attract enthusiastic adherents and converts. The International Medical Geology Association should provide a stable platform for the exchange of ideas and dissemination of information. The raft of other medical geology activities enumerated above should maintain enthusiasm and momentum for the next few years. After that the medical geologist will have to demonstrate that what we have to offer will indeed benefit society by helping to improve the quality of life for people in Europe and around the world.

\section{References}

AMBIO 2007: Special issue on medical geology. Vol. 36/1.

Appleton J.D., B. Rawlins, I. Thornton 2008: National-scale estimation of potentially harmful element ambient background concentrations in topsoil using parent material classified soil:stream-sediment relationships. - Applied Geochemistry, 23, pp. 2596-2611. 
Bowman, C., P.T. Bobrowski, O. Selinus 2003: Medical geology: New relevance in the Earth Sciences. - Episodes, 26/4, pp. 270-278.

Cave, M., H. Taylor, J. Wragg 2007: Estimation of the bioaccessible arsenic fraction in soils using near infrared spectroscopy. - Journal of Environmental Science and Health, Part A, 42, pp. 1293-1301.

Cave, M.R., J. Wragg, B. Palumbo, B.A. Klinck 2003: Measurement of the Bioaccessibility of Arsenic in UK soils. - Environment Agency, P5-062/TRI.

Centeno, J.A., F.G. Mullick, L. Martinez, H. Gibb, D. Longfellow, C. Thompson 2002: Chronic arsenic toxicity: An introduction and overview. - Histopathology, 41/2, pp. 324-326.

Centeno, J.A., CH. Tseng, G.B. van der Voet, R.B. Finkelman 2007: Global impacts of geogenic arsenic - A medical geology research case. - Ambio 36/1, pp. 78-81.

Centeno, J.A., P.B.Tchounwou, A.K. Patlolla, F.G. Mullick, L. Murakata, E. Meza, T.I. Todorov, D. Longfellow, C.G. Yedjou 2006: Environmental pathology and health effects of arsenic poisoning - A critical review. - In: Naidu, R, E. Smith, G. Owens, P. Bhattacharya, P. Nadebaum (Eds): Managing arsenic in the environment - From soil to human health, CSIRO Publishing, Australia, chapter 17, pp. 311-327.

Department for the Environment Food and Rural Affairs and the Environment Agency 2002: Assessment of risks to human health from land contamination: An overview of the soil guideline values and related research, CLR7.

Derbyshire, E. 2005: Natural aerosolic mineral dusts and human health: potential effects. - In Selinus, O., B. Alloway, J.A. Centeno, R.B. Finkelman, R. Fuge, U. Lindh, P. Smedley (Eds): Essentials of medical geology. Elsevier, Amsterdam, $820 \mathrm{p}$.

Dogan, A.U., M. Dogan, J.A. Hoskins 2008: Erionite series minerals: Mineralogical and carcinogenic properties. - Geochem. And Health, 30/4, pp. 367-381.

Earthwise 2001: Geology and health. - British Geological Survey. Issue 17.

Feder, G.L., Z. Radovanovic, R.B. Finkelman 1991: Relationship between weathered coal deposits and the etiology of Balkan endemic nephropathy. - Kidney International, 40, Suppl. 34, pp. s-9-s-11.

Geosciences et santé. 2007: Special issue of Geosciences No 5, March 2007. - BRGM. 118 p.

Haglund, B., K. Ryckenberg, O. Selinus, G. Dahlqvist 1996: Evidence of a relationship between childhood-onset type 1 diabetes and low groundwater concentration of Zinc. - Diabetes Care, 19/8, August.

Johnson, C.C., N. Breward, E.L. Ander, L. Allt 2005: G-BASE: baseline geochemical mapping of Great Britain and Northern Ireland. - Geochemistry Exploration Environment Analysis, 5, pp. $1-13$.

Kavanagh, P., M. Farago, I. Thornton, P. Elliott, W. Goessler, K.J. Irgolic 1997: Urinary arsenic concentrations in a high arsenic area of south west England. - Occupational and Environmental Medicine, 54, p. 840.

Kokki, E., J. Ranta, A. Penttinen, E. Pukkala, J. Pekkanen 2001: Small area estimation of incidence of cancer around a known source of exposure with fine resolution data. - Occupational and Environmental Medicine, 58/5, pp. 315-320.

Koljonen, T. 1975: The behavior of selenium in Finnish soils. - Annales Agriculturae Fenniae, 14, pp. 240-247.

Kousa, A., E. Moltchanova, O. Taskinen, M. Nikkarinen, J. Tuomilehto, M. Karvonen 2004: Geographical variation of Acute Myocardial Infarction (AMI) and geochemistry of local groundwater: Application of medical geology. - GFF, 126, part 1.

Kurttio, P., L. Salonen, T. Ilus, J. Pekkanen, E. Pukkala, A. Auvinen 2006: Well water radioactivity and risk of cancers of the urinary organs. - Environmental Research, 102/3, pp. 333-338.

Lahermo, P., G. Alfthan, D. Wang 1998: Selenium and arsenic in the environment in Finland. Journal of Environmental Pathology, Toxicology and Oncology, 17/3-4, pp. 205-216.

Låg, J. (Ed.) 1990: Geomedicine. CRC Press. 
Medical Geology in Developing Countries. - Two special issues of Environmental Geochemistry and Health, 29/2 2007, 30/4 2008.

Moltchanova, E., M. Rytkönen, A. Kousa, M. Viik-Kajander, M. Karvonen 2004: Zinc and nitrate in the ground water and the incidence of type 1 diabetes in Finland. - Diabetic Medicine, 21, pp. $256-261$.

Orem, W.H., G.L. Feder, R.B. Finkelman 1999: A possible link between Balkan endemic nephropathy and the leaching of toxic organic compounds from Pliocene lignite by groundwater: preliminary investigation. - Int. Jour. of Coal Geol., 40/2-3, pp. 237-252.

Palumbo-Roe, B., M.R. Cave, B.A. Klinck, J. Wragg, H. Taylor, K. O'Donnell, R.A. Shaw 2005: Bioaccessibility of arsenic in soils developed over Jurassic ironstones in eastern England. Environmental Geochemistry and Health, 27, pp. 121-130.

Rapant, S., K. Krcmova 2008: Environmental and health risk estimation for potentially toxic elements in groundwater in Slovakia. - European Geologist, 25, June, pp. 13-16.

Rapant, S., R. Salminen, T. Tarvainen, K. Krcmová, V. Cvecková 2008: Application of a risk assessment method to Europe-wide geochemical baseline data. - Geochemistry: Exploration, Environment, Analysis, 8.

Rawlins, B.G., K. O'Donnell, M. Ingham 2003: Geochemical survey of the Tamar catchment (southwest England). - British Geological Survey, CR/03/027.

Reimann, C., M. Ääräs, V. Chekushin-. et al. 1998: Environmental Geochemical Atlas of the Central Barents Region. - Special Publication, NGU-GTK-CKE. Geological Survey of Norway, Trondheim

Reimann, C., U. Siewers, T. Tarvainen et al. 2003: Agricultural Soils in Northern Europe: A Geochemical Atlas. - Geologisches Jahrbuch, Sonderhefte, Reihe D, Heft SD 5. Schweizerbart'sche Verlagsbuchhandlung, Stuttgart.

Salminen, R. (Chief-editor), M.J. Batista, M. Bidovec, A. Demetriades, B. De Vivo, W. De Vos, M. Duris, A. Gilucis, V. Gregorauskiene, J. Halamic, P. Heitzmann, A. Lima, G. Jordan, G. Klave, P. Klein, J. Lis, J. Locutura, K. Marsina, A. Mazreku, P.J. O'Connor, S.Å. Olsson, R.-T. Ottesen, V. Petersell, J.A. Plant, S. Reeder, I. Salpeteur, H. Sandström, U. Siewers, A. Steenfelt, T. Tarvainen 2005: Geochemical Atlas of Europe. Part 1 - Background Information, Methodology and Maps. - Geological Survey of Finland, Espoo.

Selinus, O., A. Frank, V. Galgan 1996: Biogeochemistry and metal biology-An integrated Swedish approach for metal related health effects. - In: Appleton, D., R. Fuge, J. McCall (Eds): Environmental geochemistry and Health in Developing Countries, Special Publication, Geological Society of London, 113, pp. 81-89, Chapman and Hall.

Selinus, O., A. Frank 1999: Medical geology. - In: Möller, L. (Ed.): Environmental medicine. Joint Industrial Safety Council, Stockholm, pp 164-183.

Selinus, O., B. Alloway, J.A. Centeno, R.B. Finkelman, R. Fuge, U. Lindh, P. Smedley (Eds) 2005: Essentials of medical geology. - Elsevier, Amsterdam, $820 \mathrm{p}$.

Selinus, O., B.Alloway, J.A. Centeno, R.B. Finkelman 2008: The medical geology revolution - the evolution of an IUGS initiative. - Episodes, 30/4.

Skinner, C., A. Berger (Eds) 2000: Geology and Public Health - Closing the Gap, 2000. Oxford Press. Smedley, P., D.G. Kinniburgh 2005: Arsenic in groundwater and the environment. - In: Selinus, O., B. Alloway, J.A. Centeno, R.B. Finkelman, R. Fuge, U. Lindh, P. Smedl (Eds) 2005: Essentials of medical geology. Elsevier, Amsterdam, 820 p.

Tatu, C.A., W.H. Orem, R.B. Finkelman, G.L. Feder 1998: The etiology of Balkan Endemic Nephropathy: still more questions than answers. - Environmental Health Perspectives, 106/11, pp. 689-700.

Wragg, J. 2005: A study of the relationship between arsenic bioaccessibility and its solid phase distribution in Wellingborough soils. - Nottingham.

Wragg, J., M. Cave, P. Nathanail 2007: A study of the relationship between arsenic bioaccessibility and its solid-phase distribution in soils from Wellingborough, UK. - Journal of Environmental Science and Health, Part A, Vol. 42, pp. 1303-1315. 